\title{
ENSAIO DA VIDA E MORTE DE UM PORCO CAIPIRA: ABATE E MANIPULAÇÃO
}

\author{
Maria Isabel Trivilin Pereira ${ }^{1}$
}

O dia amanhece ainda mais cedo no campo quando é dia de abate. Encerra-se um ciclo e inicia-se outro até que a proteína acabe e seja preciso novamente matar um animal. Na casa de dona Luzia e seu Luiz, uma dona de casa e um agricultor sexagenários, são mortos um boi cerca de duas vezes ao ano, um porco a cada dois meses e quinze frangos a cada quarenta dias, o que é muito e é referido sempre como fartura em relação às décadas anteriores. Isto serve a uma família de pouco mais de dez pessoas, sem contar os parentes e vizinhos que fazem parte do amplo sistema de troca de alimentos ${ }^{2}$. Os animais são mortos com a ajuda de familiares e amigos e o processo de dois ou três dias é um misto de trabalho e gracejo, "tudo para tornar o longo dia mais fácil"3.

Jogar conversa fora quando se tem uma quantidade considerável de alimento a tratar e vários procedimentos desde o corte à extração da banha, do couro e à fabricação da linguiça, do chouriço e do codeguim, faz parte, como argumentam os próprios agricultores, e expõe uma prática que se difere muito da produção em larga escala. Debocham uns dos outros, insultam-se em piada e para um estrangeiro, causaria espanto um clima de tamanha descontração em meio a cenas que podem chocar: pedaços de animal fatiados que não se parecem com bifes e carnes em bandejas, mas fazem alusão direta a partes de seu corpo vivo e à lembrança da morte.

O cenário é de uma comunidade rural no município de Ubiratã, região centro ocidental paranaense, de aproximadamente cento e trinta famílias, chamada São João. Conhecida por sua grande festa junina e uma fogueira que chega aos trinta metros de

\footnotetext{
${ }^{1}$ Universidade Estadual de Maringá, Brasil. Email: beltrivilin@hotmail.com ORCID id: https://orcid.org/0000-0001-7678-6773

2 Verifica-se sobretudo no tocante à carne de porco e caça de pelo, não compreendendo carne de vaca, galinha e caça de pena. Não apenas no bairro estudado, mas em toda a região e, segundo os velhos, desde sempre, é hábito - quase se diria instituição - a oferta daqueles tipos de carne aos vizinhos imediatos, que moram à vista ou constituem uma unidade vicinal.

Quando se mata um porco, ou uma caça (capivara, veado, paca, cutia, quati, tatu), envia-se um pedaço a cada vizinho. Segundo a boa tradição de cortesia deve-se mandar a todos; na prática, aos escolhidos, por proximidade ou preferência. Às vezes os vizinhos são tantos, ou o animal tão pequeno, que quase nada sobra ao ofertante. Conforme o padrão ideal, porém, ficaria malvisto quem se mostrasse parcimonioso em proveito próprio. (Candido, 1971)

3 Frase repetida pelos moradores algumas vezes.
} 
altura, o lugar que antes abrigava mais que o dobro da população, mantém ainda certas práticas, hábitos, crenças e manifestações de um modo de vida tradicional que não volta mais.

A curiosidade pela relação entre homens e animais, principalmente os que são transformados em alimento, surgiu de um trabalho etnográfico durante a típica festa de São João, em junho de 2018, na referida comunidade que é também onde nasci e cresci. Esta exposição surge da ideia de uma dona de casa e trabalhadora do campo, em uma semana de visita que coincidiu com o abate de um porco de mais de trezentos quilos. Acompanhei o processo durante os árduos dias na intenção de ilustrar, para além das palavras, um momento bastante importante no ciclo do ano para os moradores do local, na obtenção e manipulação de alimento.

A quem chegasse na casa dos agricultores na noite do dia do abate - onde ocorria um churrasco de carneiro para que o trabalho fosse recompensado - a dona de casa corria mostrar o serviço como um troféu: partes de um grande porco repartidos e pendurados no teto de um pequeno rancho construído para a lida com a carne. Os pedaços com sangue escorrendo giravam nos ganchos e Dona Luzia mostrava com carinho e satisfação: "olha, que lindo!”

Fala-se de trabalhadores da roça que experimentaram a falta, a ausência de carne e de alimento além da sobrevivência, com semelhanças ao caipira paulista estudado por Antônio Candido:

Se verá, então, que este se nutria principalmente ao modo dos sertanistas, como quem se contesta com o mínimo para não demorar as interrupções da jornada. Este mínimo alimentar corresponde a um mínimo vital, e a um mínimo social: alimentação apenas suficiente para sustentar a vida; organizar social limitada à sobrevivência do grupo. (Candido, 1971)

Há a tentativa de representar, tanto quanto possível, a vivacidade do processo: os risos, zumbidos, piadas e vozes que o protagonizam. As imagens parecem, em alguns momentos, paradoxais: subsiste a vida e a morte. Enquanto no rancho o bicho morto é fatiado, as crianças brincam com as ovelhas à vista dos pais e avós, e quando algum amigo que ainda não conhece as criações vêm ajudar, entre um processo e outro, alguém da casa faz questão de mostrar os lindos bichos que cria ali.

Depois de retirar toda a gordura e colocar para cozinhar no tacho de ferro, Dona Luzia conduz Dona Ivone a ver os novos porquinhos nascidos há poucos dias: "os bichinhos são lindos demais, né?", as comadres comentam. Acariciam alguns, jogam um 
pouco mais de quirela às aves e conversam sobre o andar de galos majestosos. $\mathrm{O}$ momento é interrompido pelo grito de um dos homens dizendo que era hora de recomeçar o trabalho e voltar a fatiar o último animal morto.

$\mathrm{O}$ ciclo não parece se encerrar. Pelo contrário, traz na bagagem um modo de vida, sobrevivência e uma herança de homens e mulheres do campo que seguem ainda hoje com criações domésticas para matar, comer, trocar e relembrar.

\section{REFERÊNCIAS}

CANDIDO, Antonio. Os Parceiros do Rio Bonito, Estudo sobre o caipira paulista e a transformação dos seus meios de vida. São Paulo: Livraria Duas Cidades, 1971.

GEERTZ, Clifford. Obras e Vidas, O antropólogo como autor. Editora UFRJ, 2009.

Fotos de

TRIVILIN, Maria Isabel. Fotos de Comunicação São João. Ubiratã, 25-26-27 jul. 2019.

Recebido 08/08/2019

Aprovado 10/04/2020 

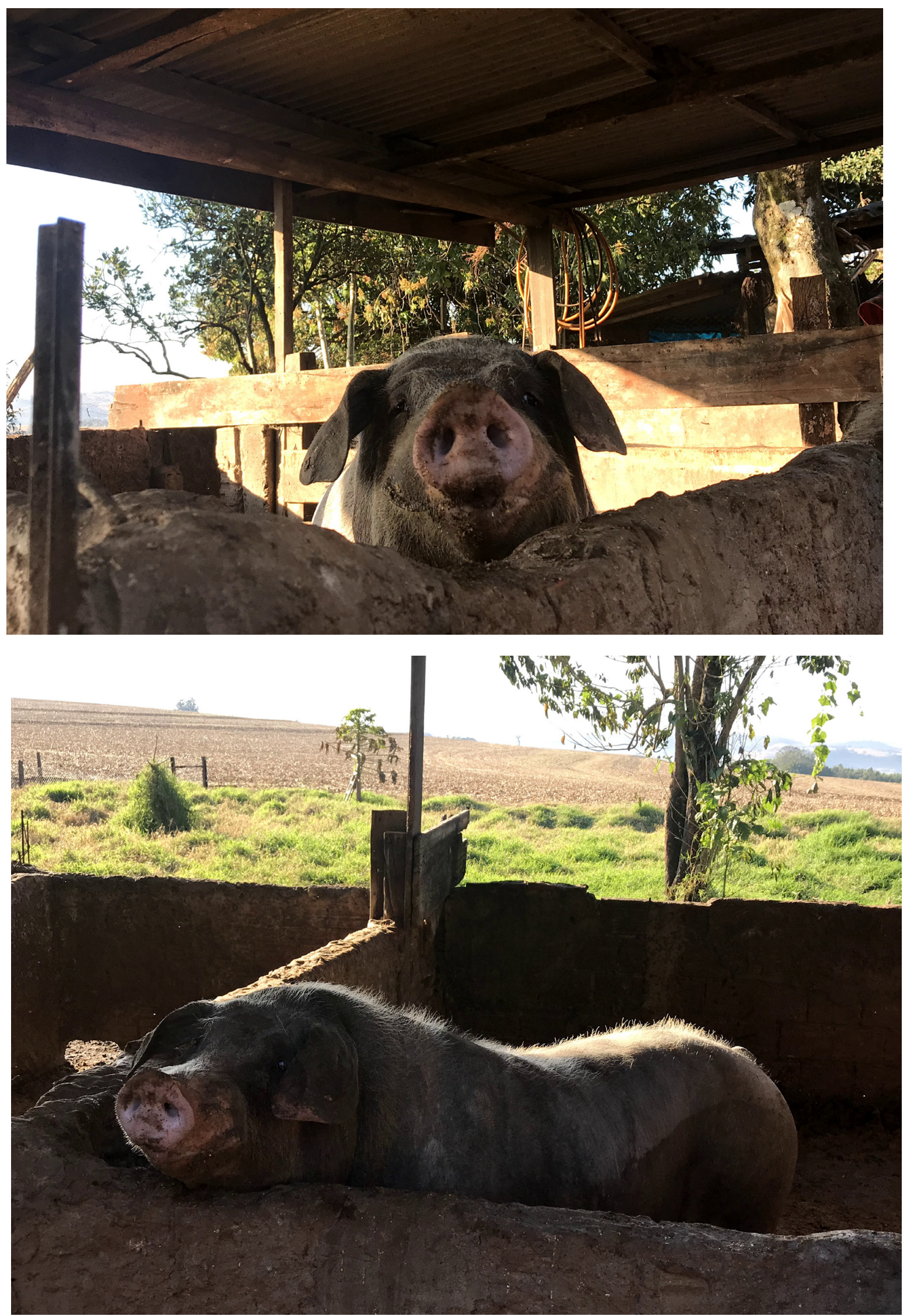

Imagens 1, 2: Criação doméstica de porcos. 


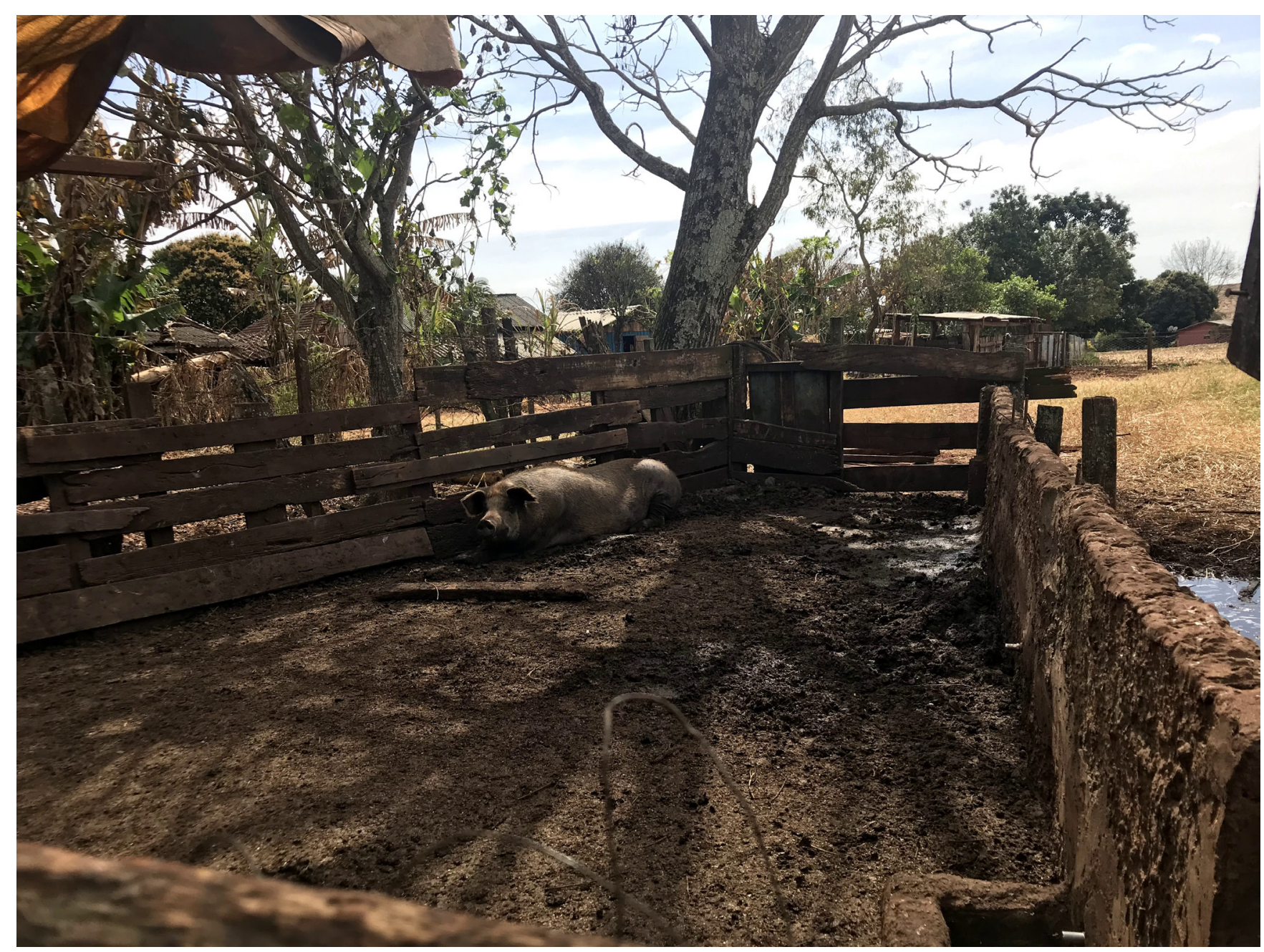

Imagem 3: Porco Tobias. 


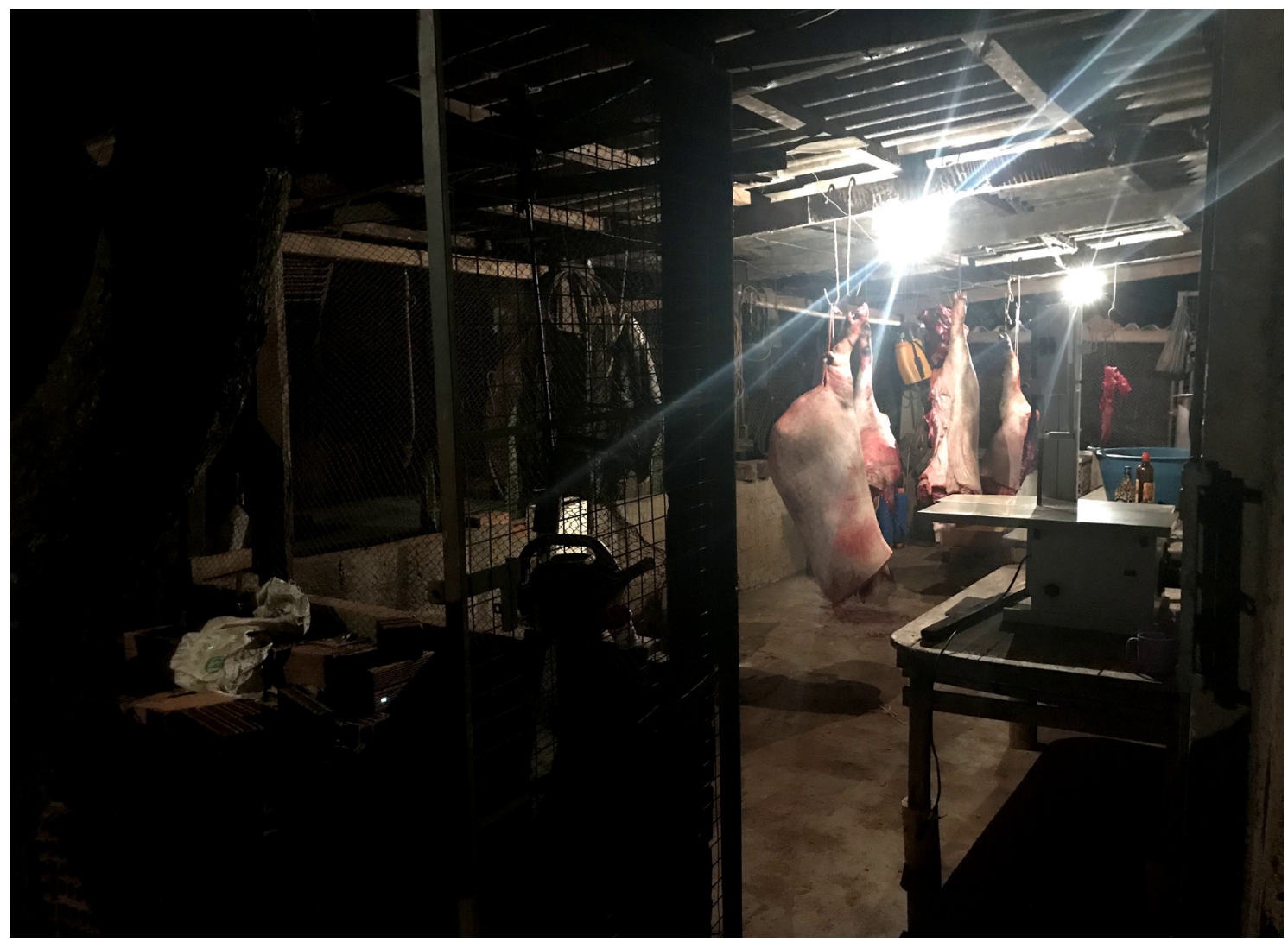

Imagem 4: Depois de morto e fatiado, as partes são penduradas no rancho.

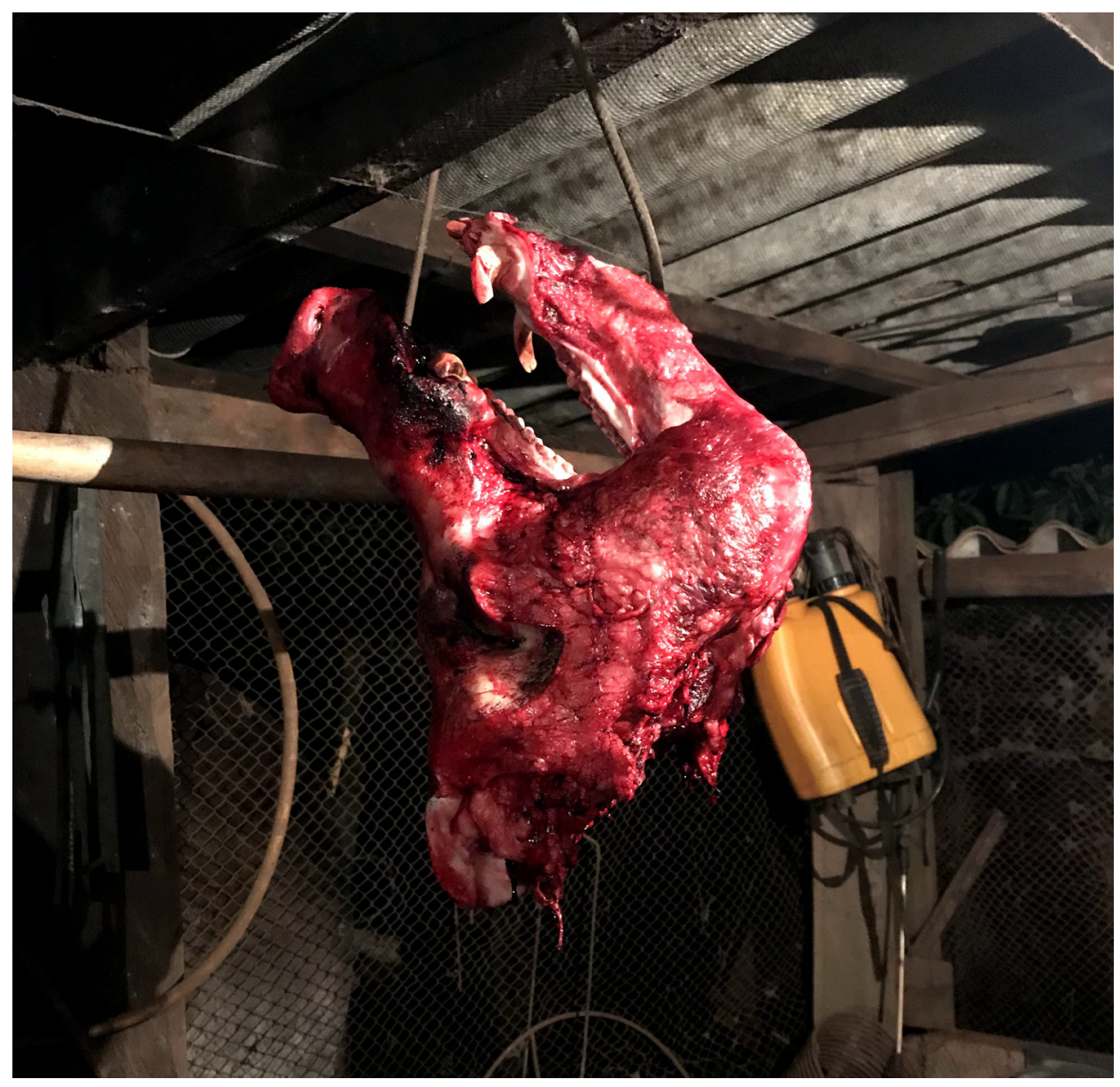


Imagem 5: Cabeça de porco em carne viva no dia do abate, noite anterior à manipulação.
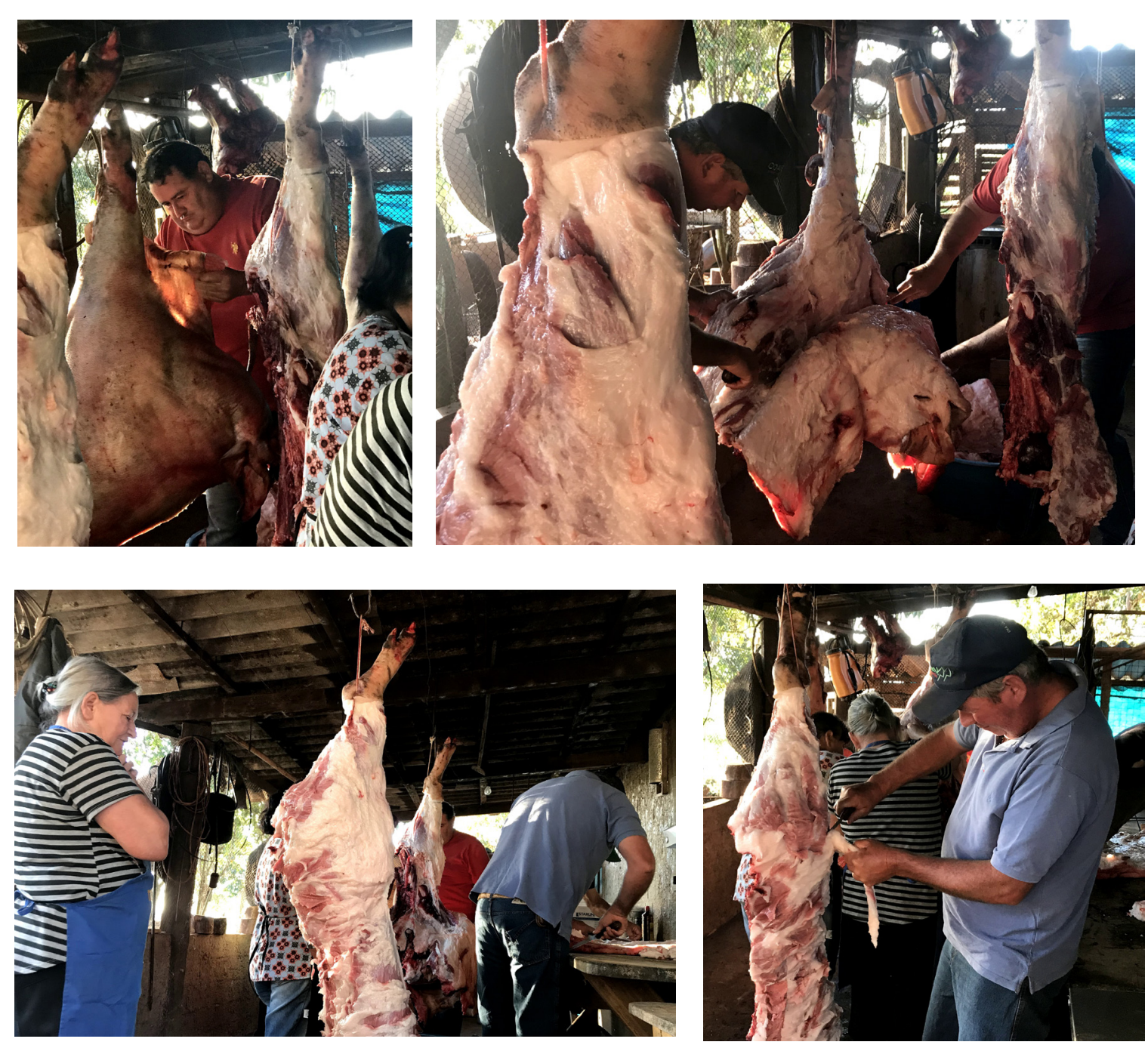

Imagens 6, 7, 8 e 9: Antes o couro, depois toda a gordura é retirada. 

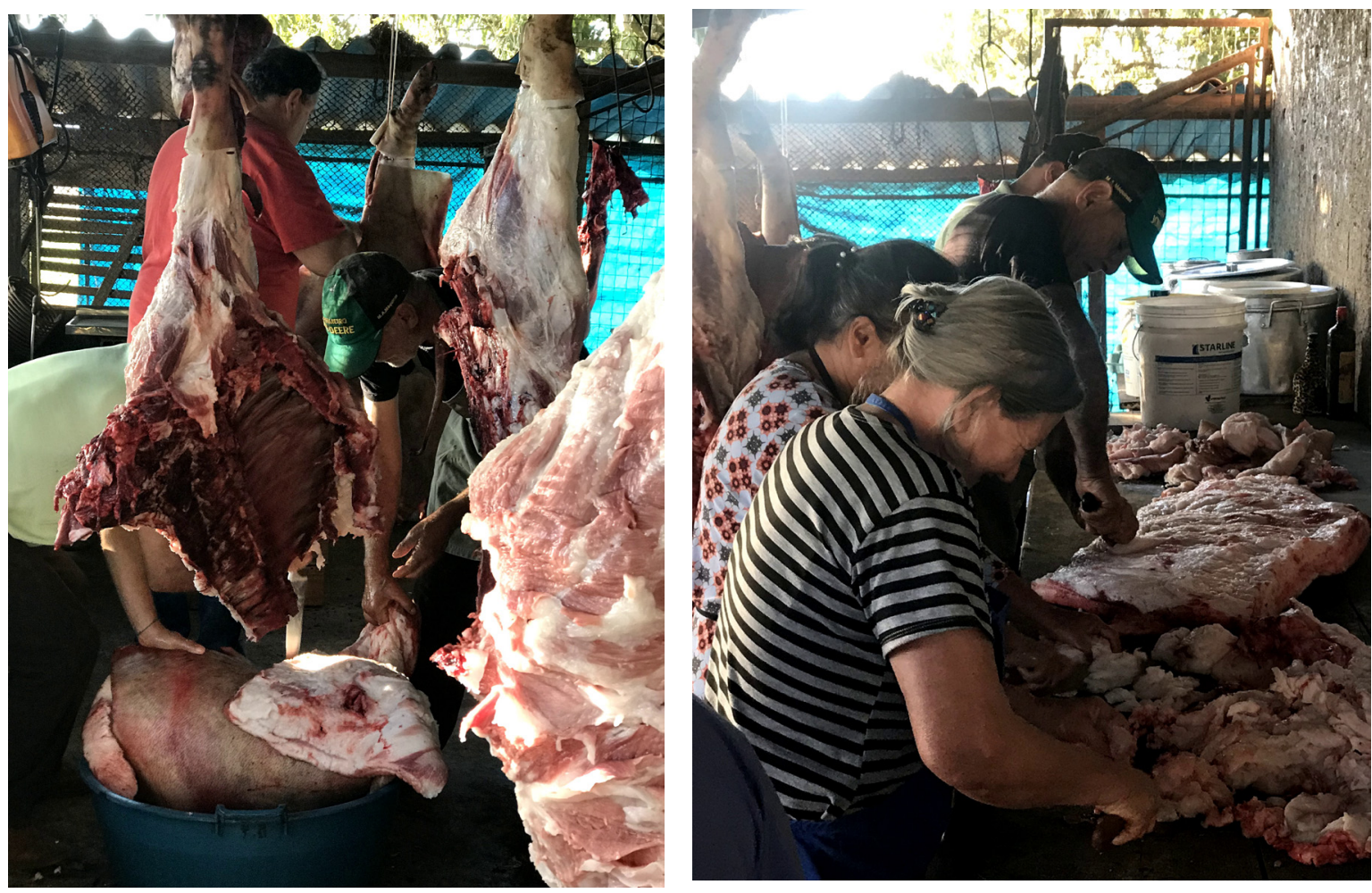

Imagens 10, 11: A banha é fatiada em pedaços pequenos. 


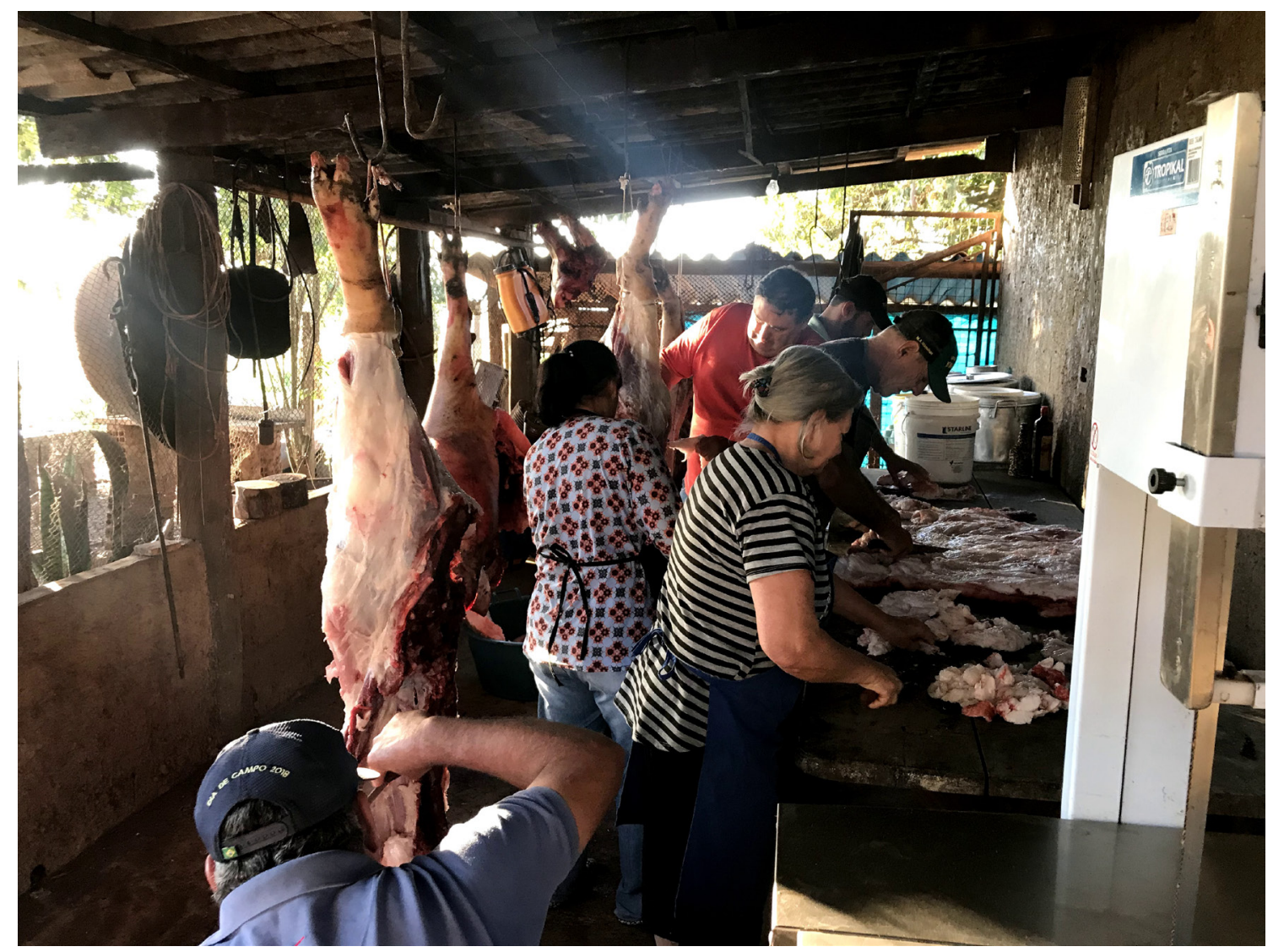

Imagem 12: $\mathrm{O}$ processo.

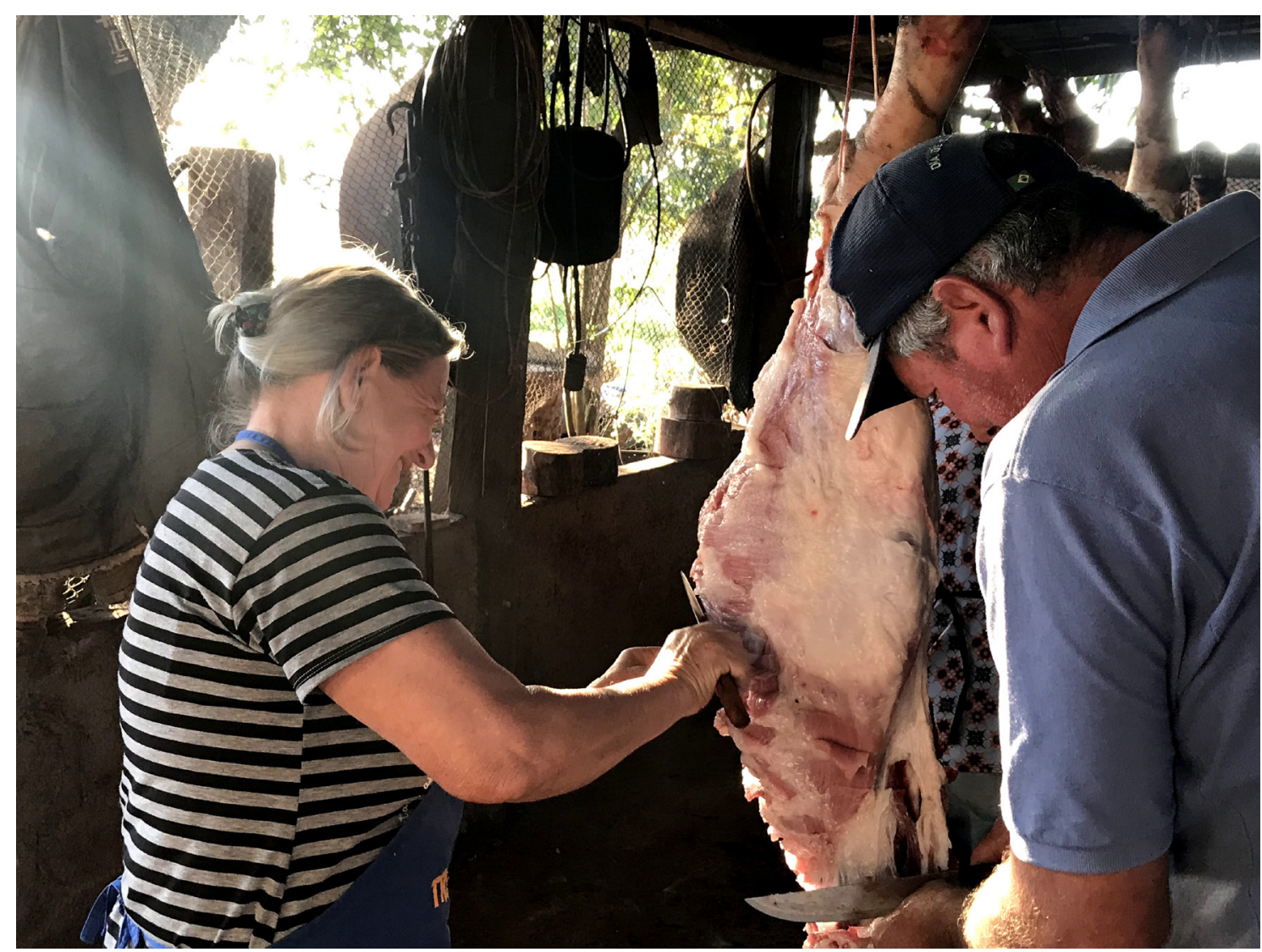

Imagem 13: Mãe e filho. 

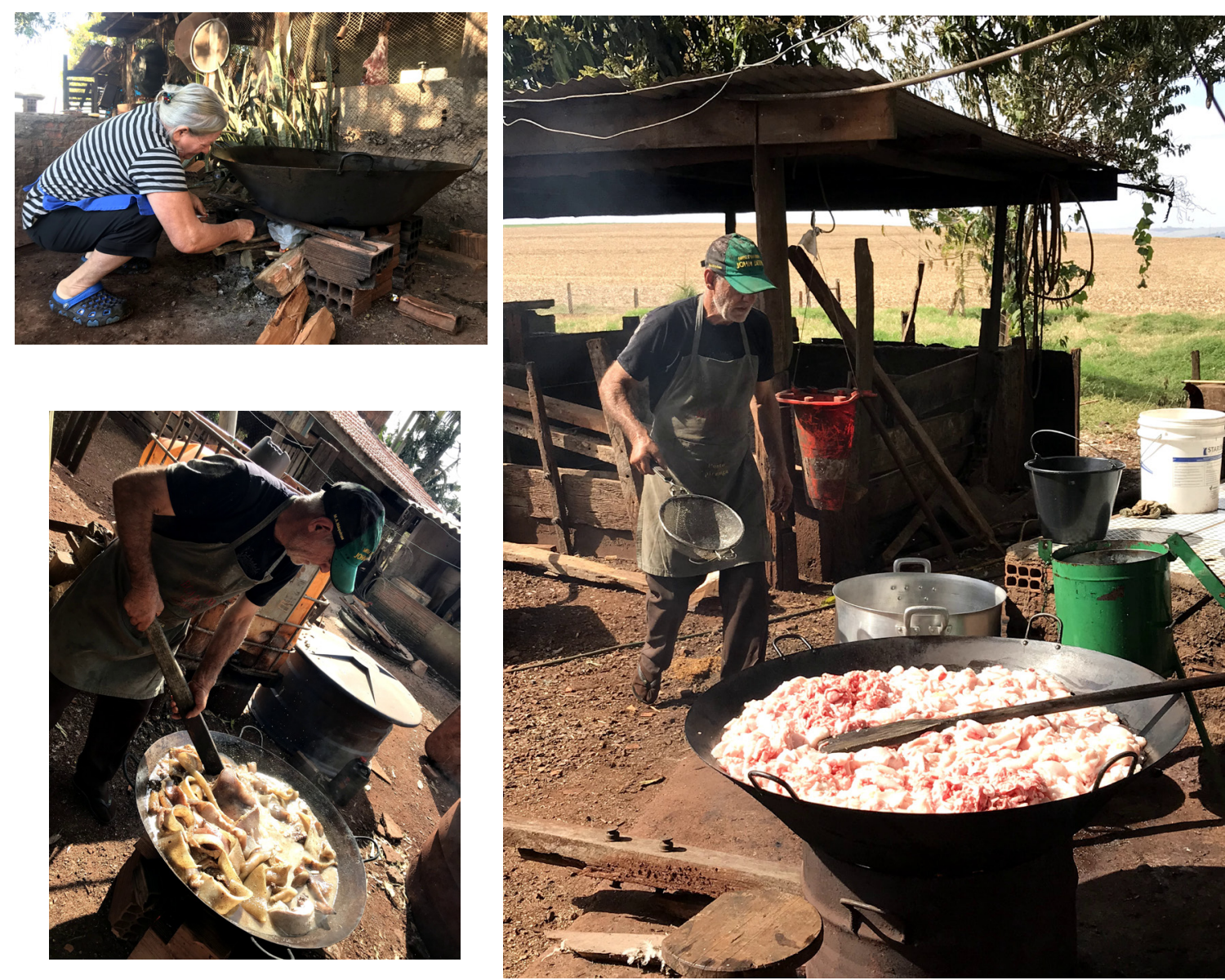

Imagens 14, 15, 16: O fogo é aceso e a banha é posta no tacho até derreter. 


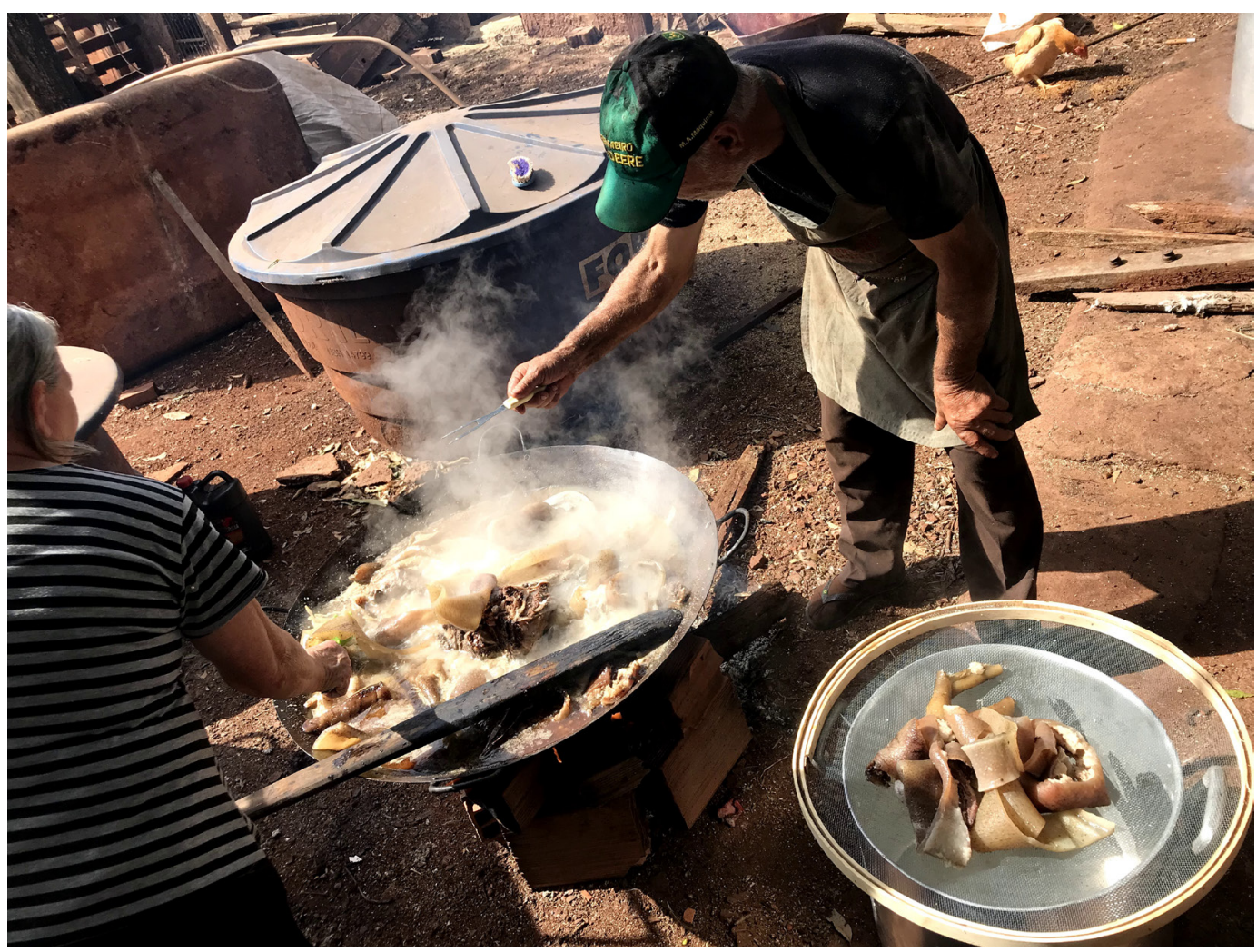

Imagem 17: Enquanto isso, o couro cozinha em outro tacho de ferro.

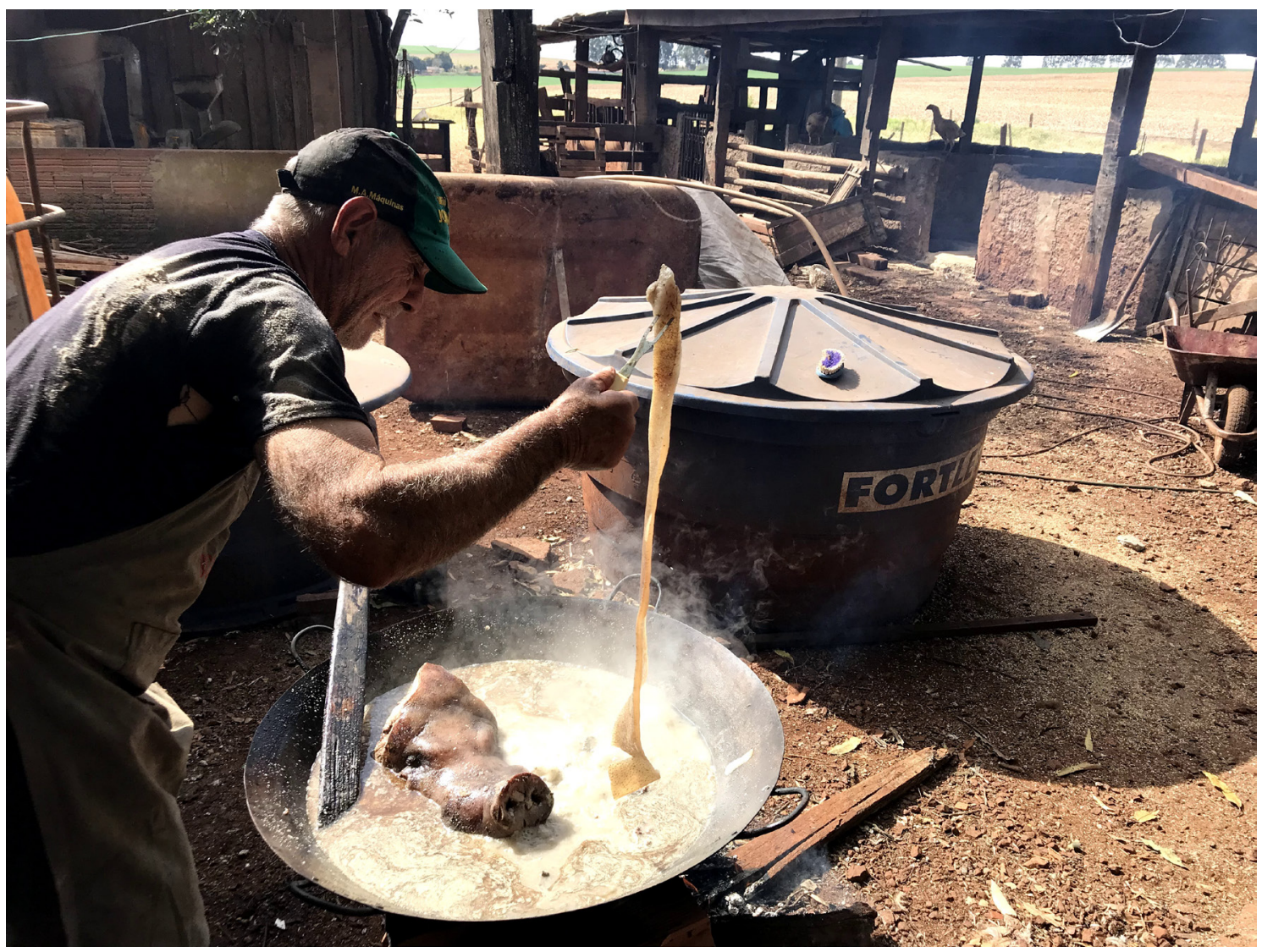

Imagem 18: A cabeça é escaldada para depois retirar a carne e moê-la, junto à parte do couro, e fazer o codeguim. 


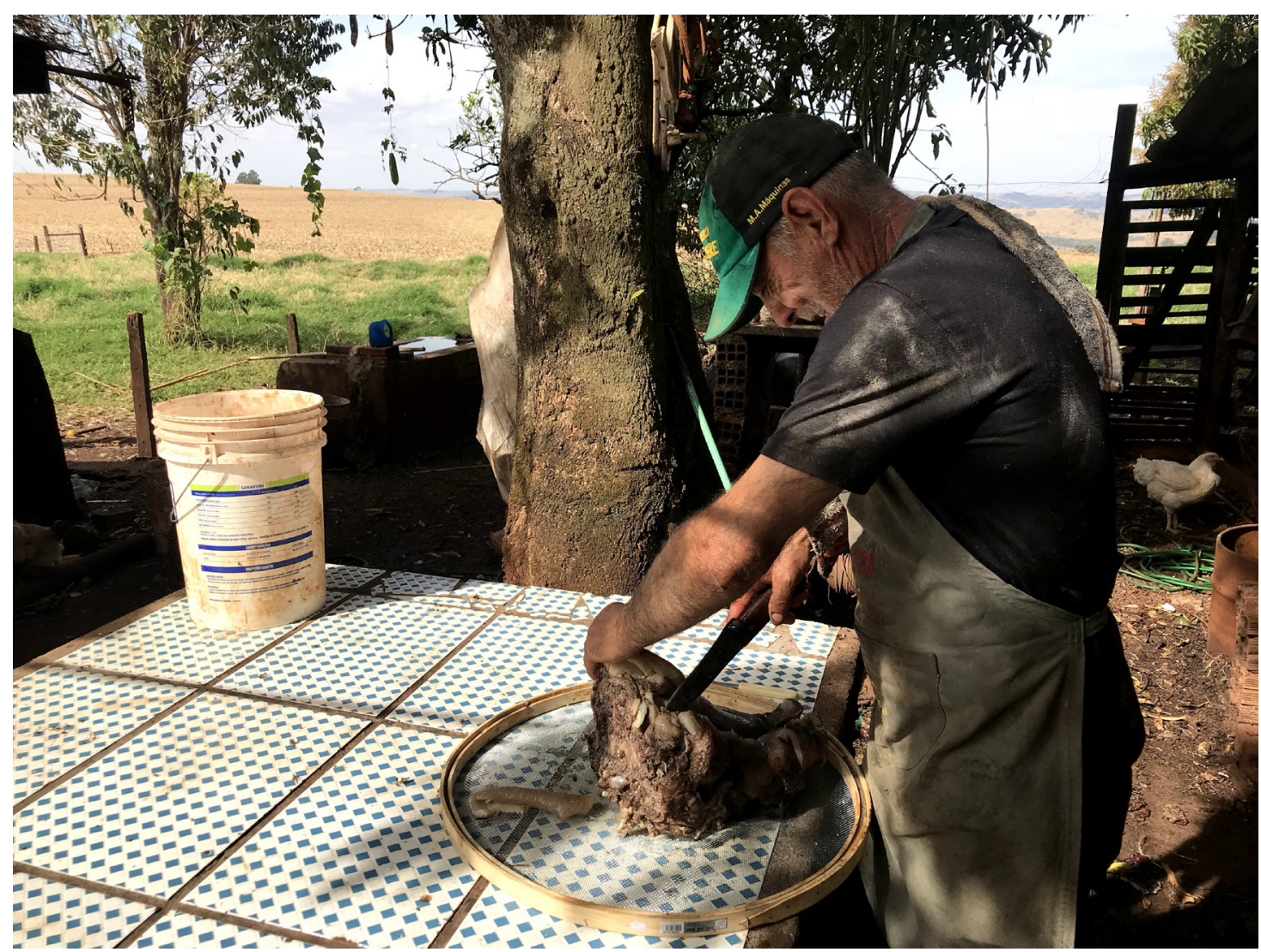

Imagem 19: Desossando a cabeça de porco. 


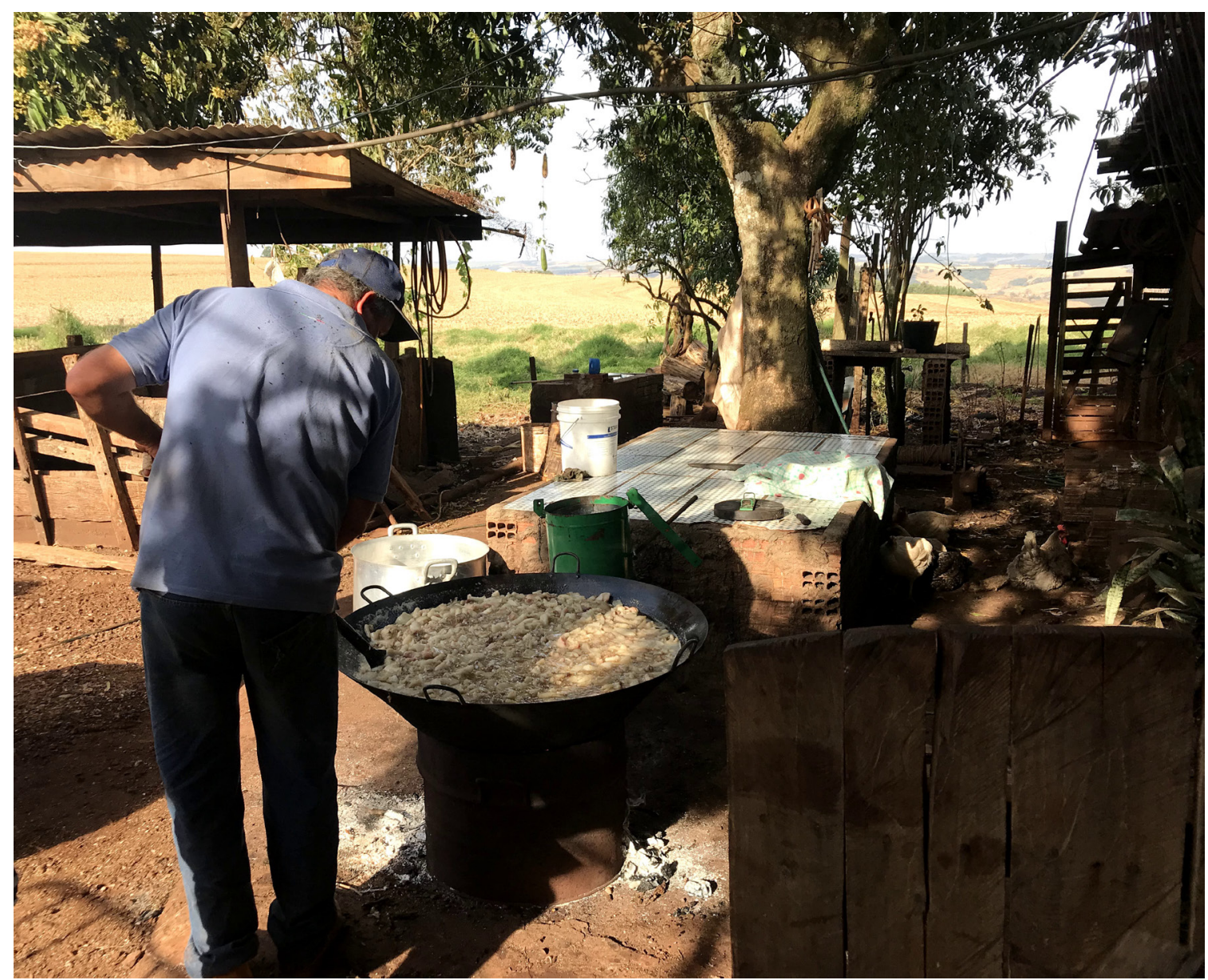

Imagem 20: Derretimento da banha.
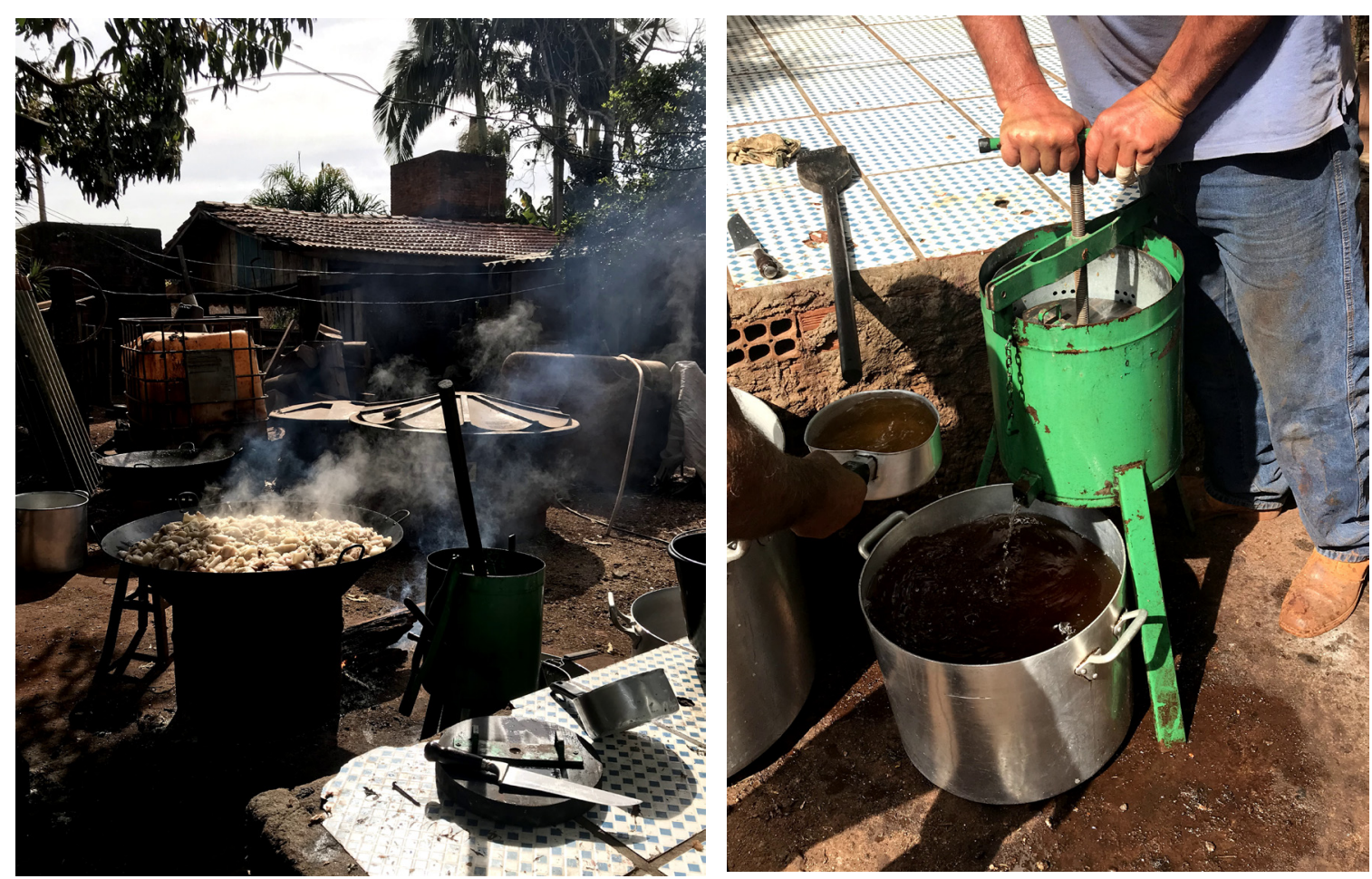

Imagens 21, 22: Depois de cozida e derretida, ela é espremida, resultando em oito latas de gordura. 


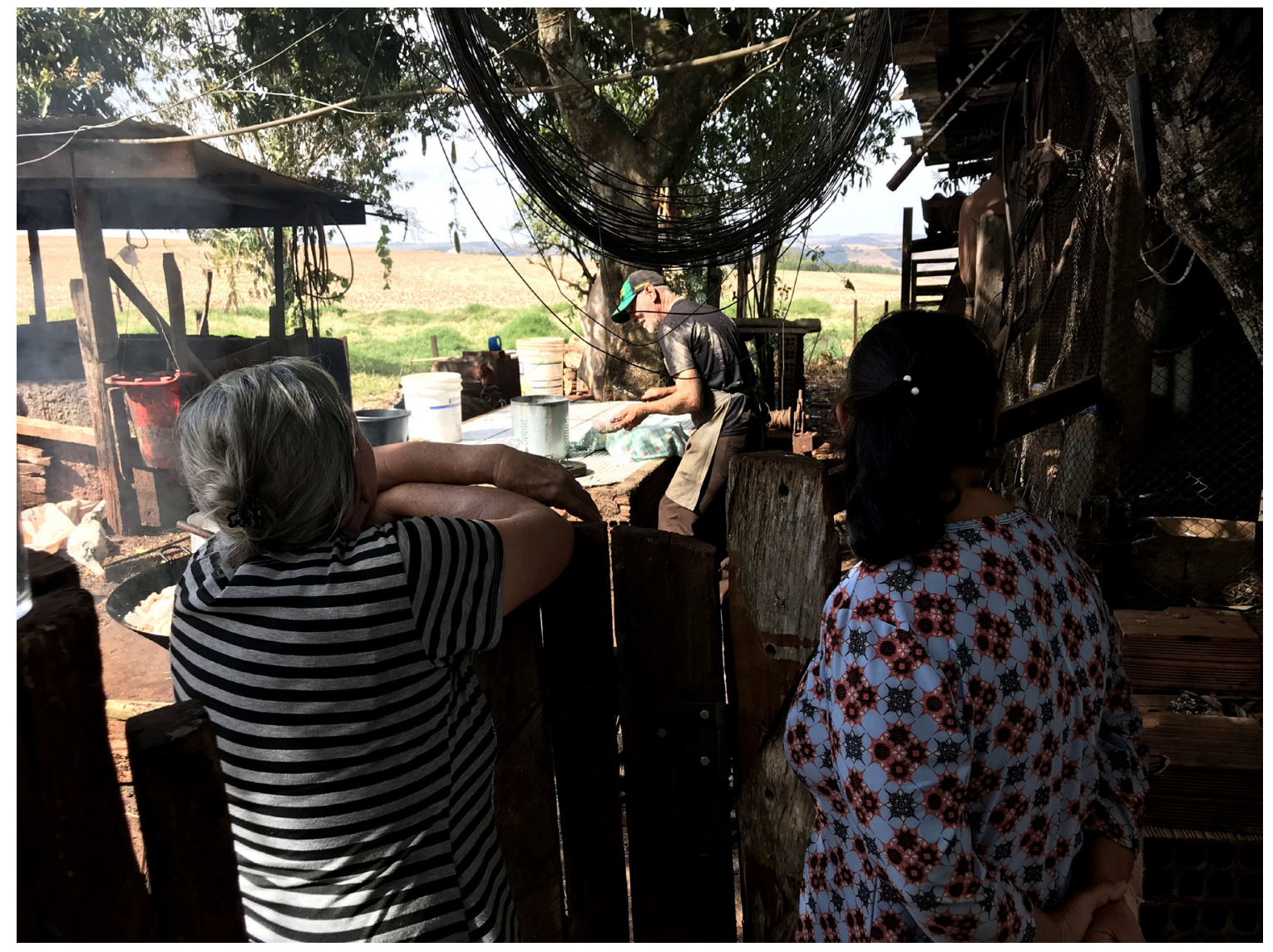

Imagem 23: O olhar das mulheres. Pausa para o café. 


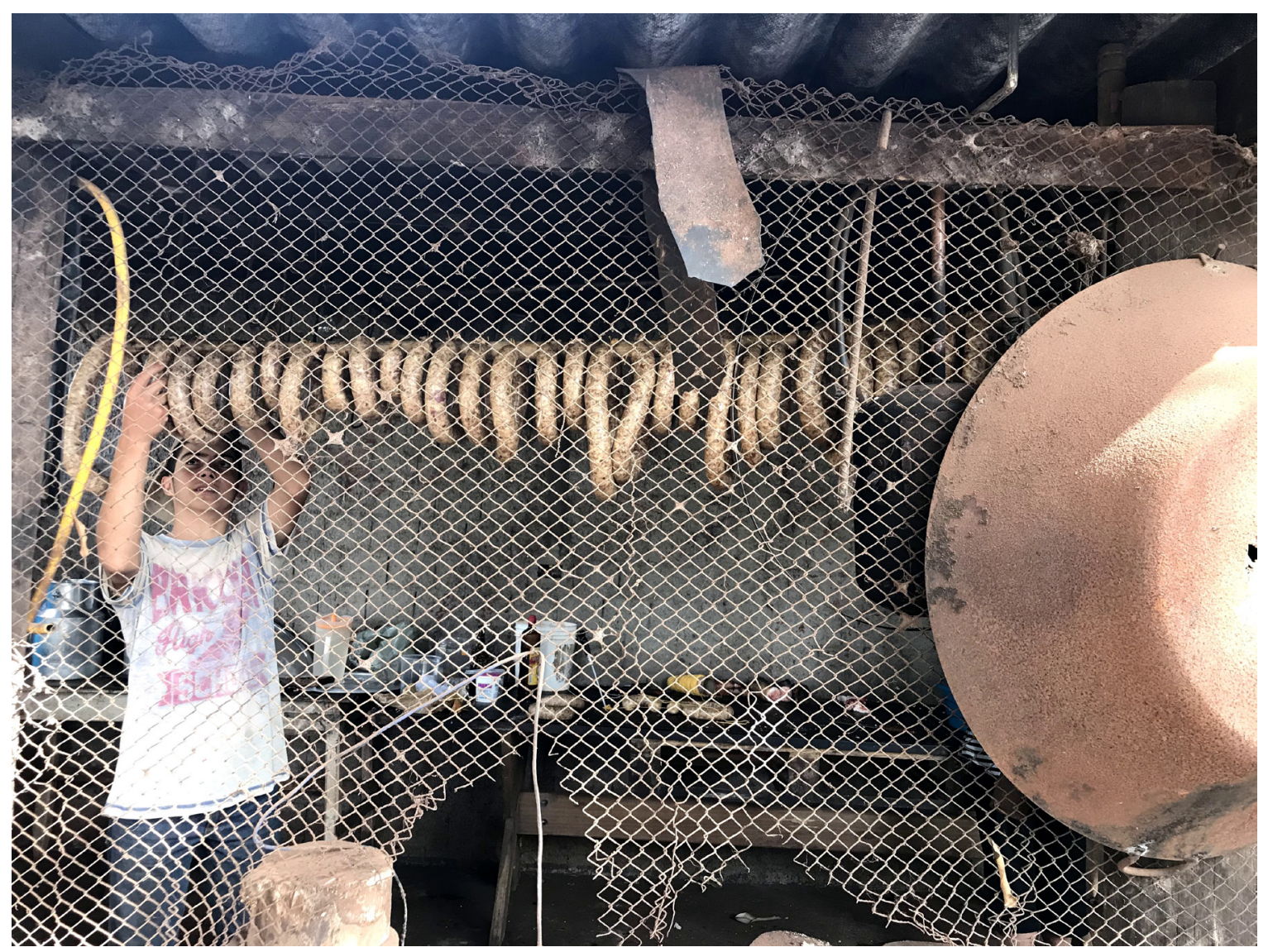

Imagem 24: A linguiça é ensacada e amarrada um varal de bambu. $\mathrm{Na}$ foto, Diego, 15 anos. 

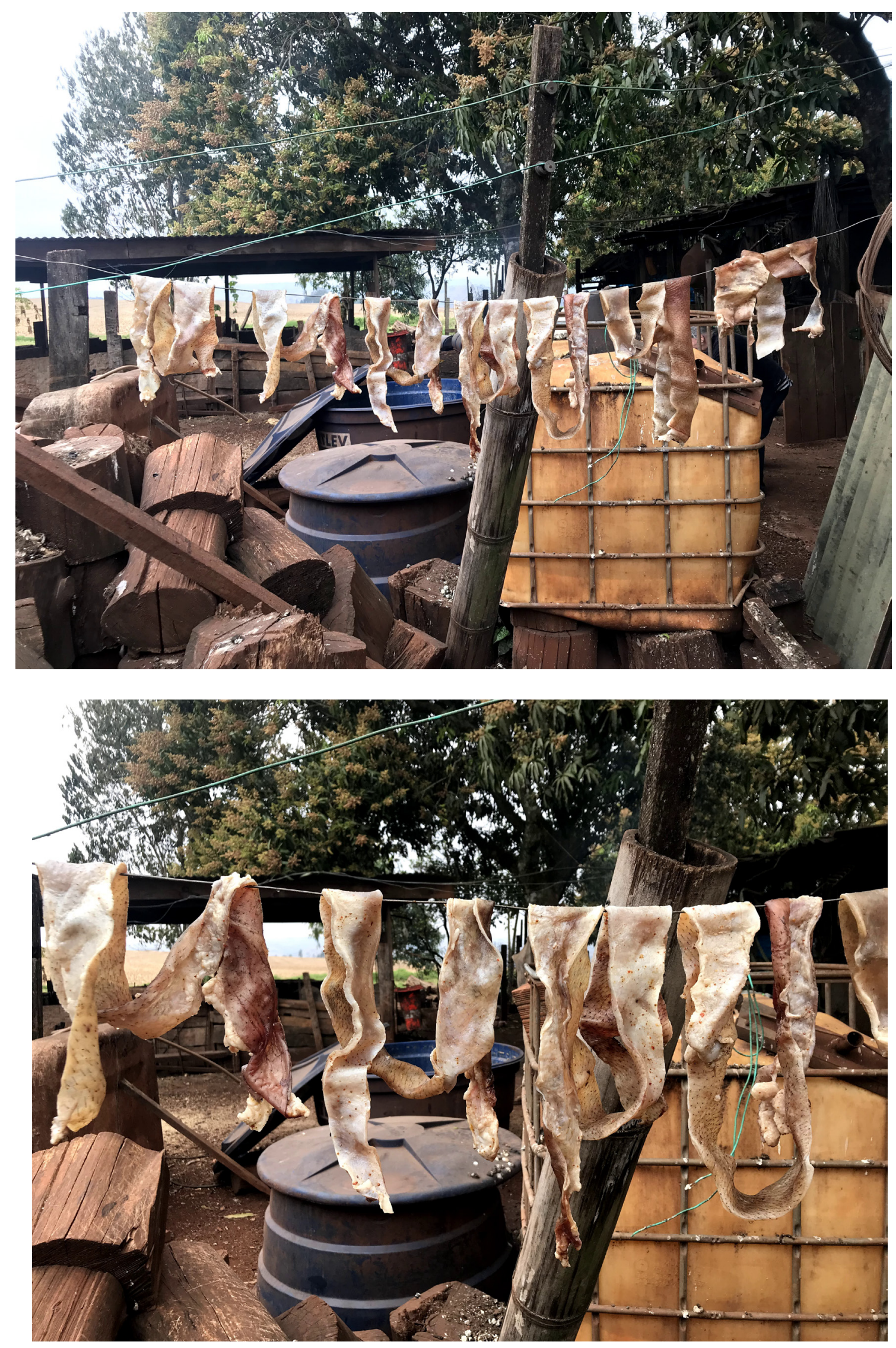

Imagens 25, 26: Parte do couro é moída, a outra é posta para secar.

Depois se faz o torresmo 


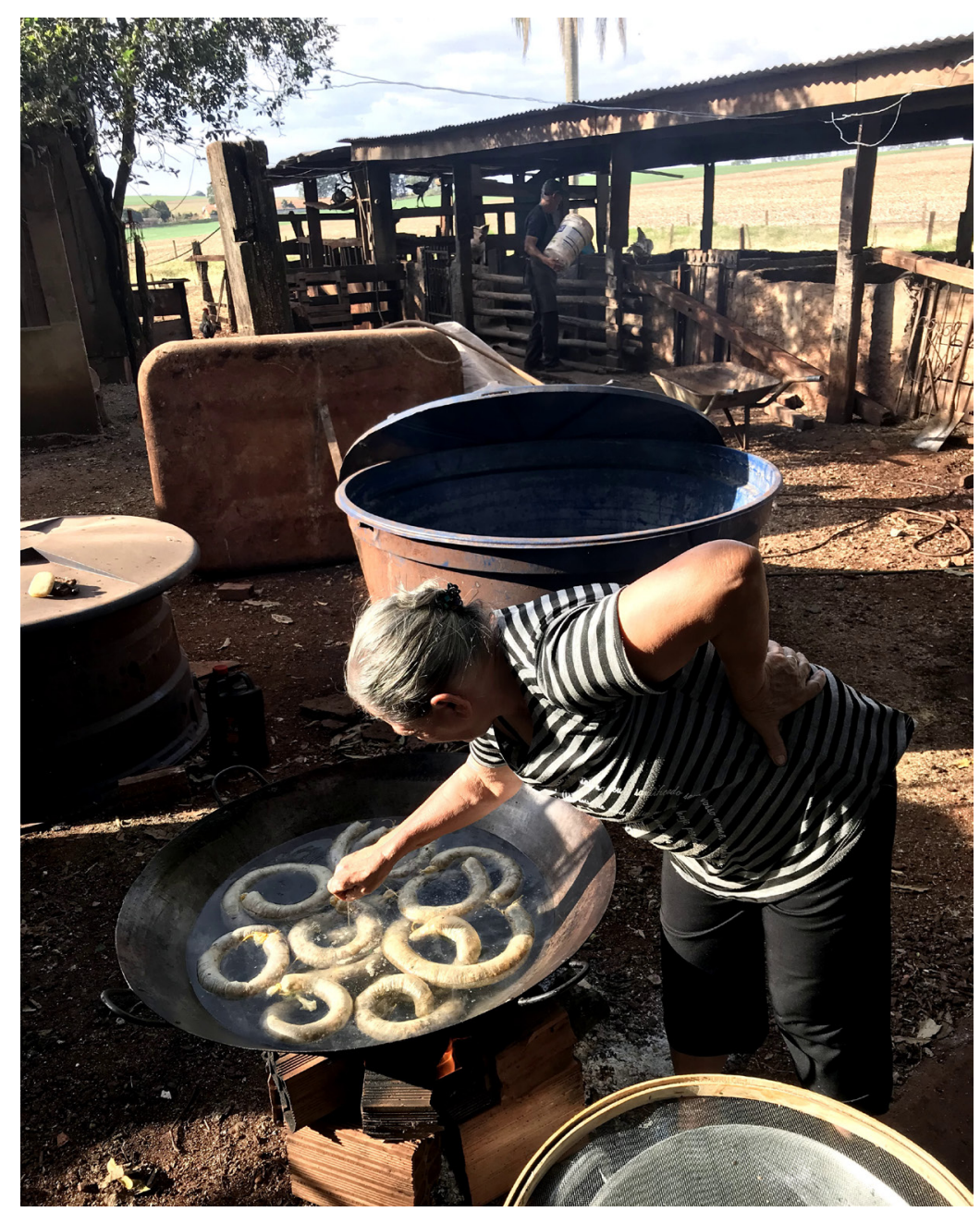

Imagem 27: Após cozinhar o couro, ele é moído e ensacado com carne de outras partes e volta novamente ao tacho. Este é o codeguim. 

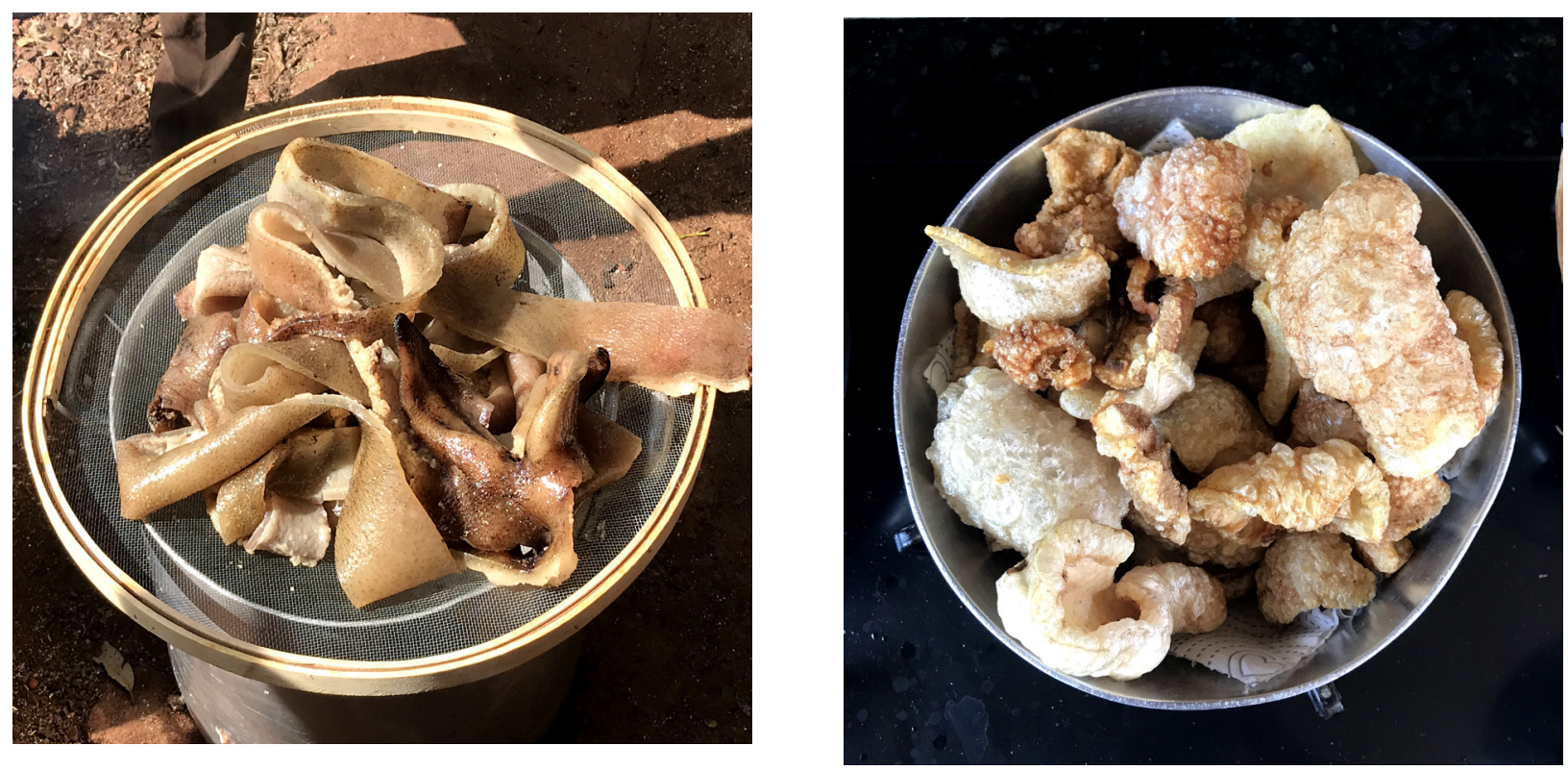

Imagens 28, 29: Junto ao toucinho, o torresmo. Na primeira, o couro. 


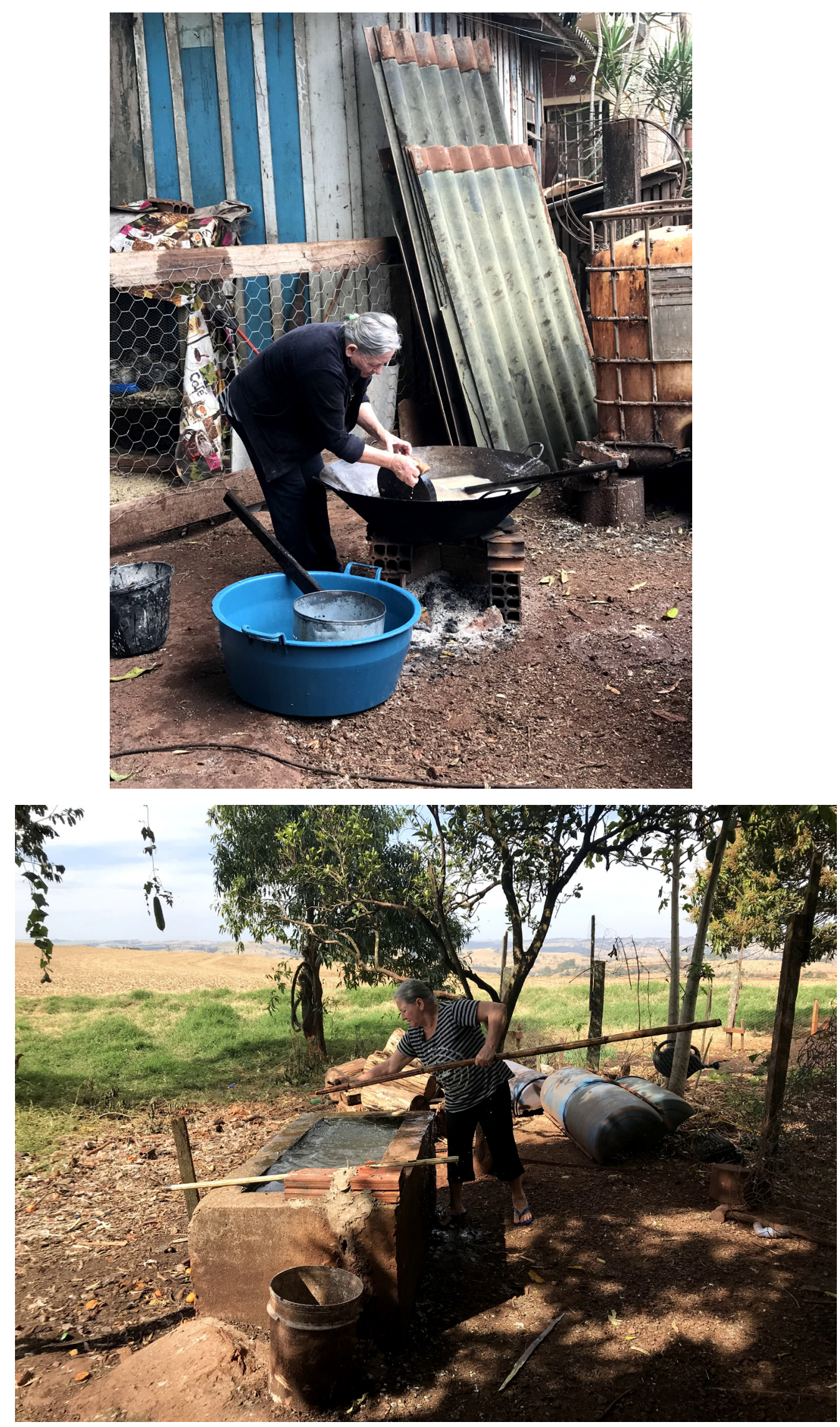

Imagens 30, 31: A limpeza. 


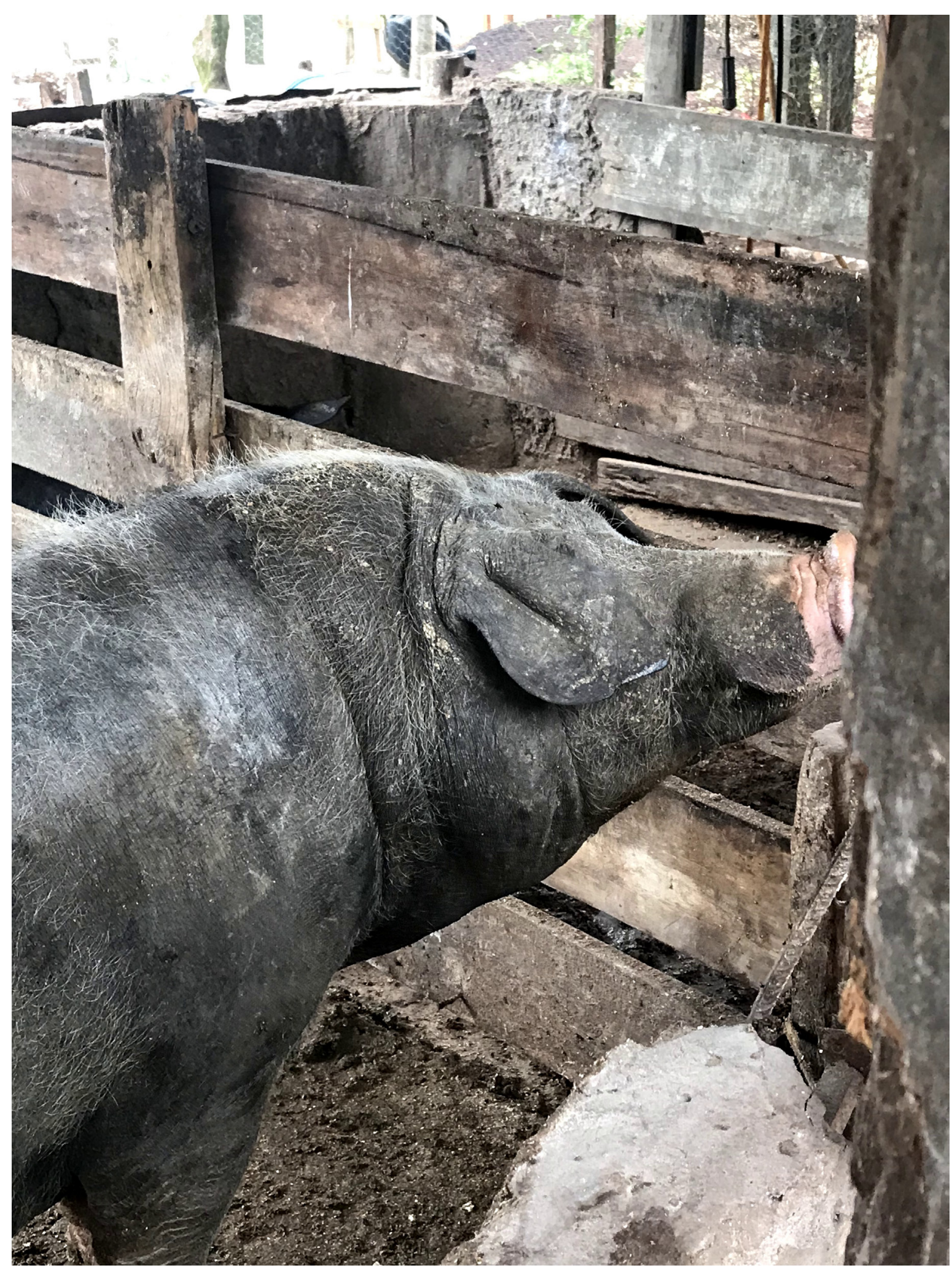

Imagem 32: Focinho de porco caipira. 


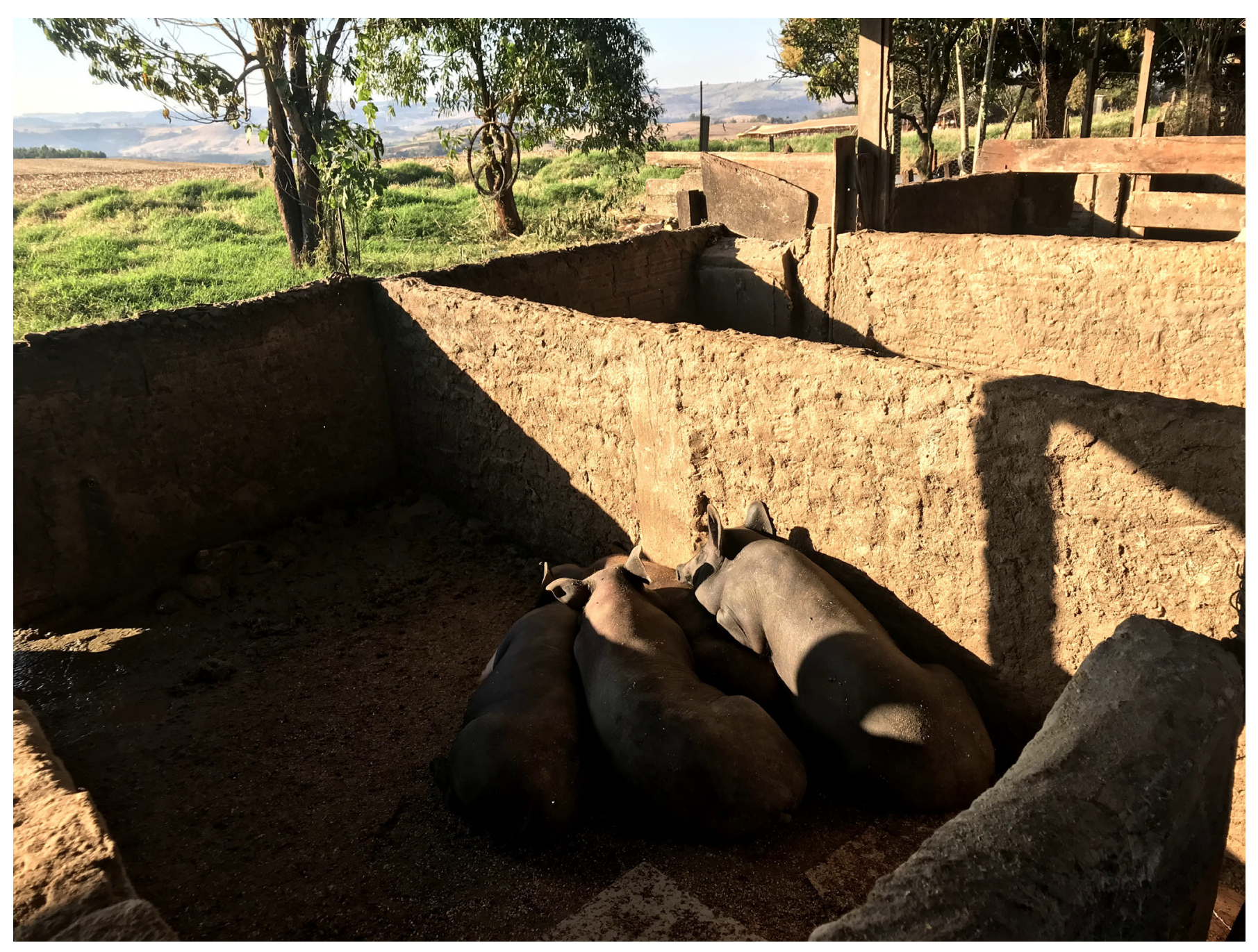

Imagem 33: Os três porcos, o sol e a mãe.

O ciclo se reinicia. 